\title{
EVALUASI HUBUNGAN BIAYA INVESTASI TERHADAP KUALITAS KENYAMAN PADA PERUMAHAN
}

\author{
Pratiwi Dian Ilfiani' ${ }^{1}$, Suprapto Siswosukarto',Djoko Sulistyo ${ }^{1}$ \\ ${ }^{1}$ Departemen Teknik Sipil dan Lingkungan, Fakultas Teknik, Universitas Gadjah Mada, Yogyakarta \\ Email: pratiwidianilfiani@gmail.com
}

\begin{abstract}
The demand for housing has never stopped because the population growth always increased. Technical Guidelines for the Construction of Healthy Houses issued by the Minister of Regional Regional Development states that a house as a place of residence must meet indoor health and comfort requirements which is influenced by lighting, airing, air temperature and humidity. This study uses natural lighting, natural ventilation, room humidity and acoustic comfort as variables. The object of this study is limited to the building area of a maximum of $70 \mathrm{~m}^{2}$ with four sample that maintain the original house shape from the design of the developer. Three out of four houses showed the relation between investment and indoor comfort, the higher investment improve indoor comfort. But, one of them showed different pattern, this is because the investment value is influenced by the accessibility of site and buildings. This study found that indoor comfort is influenced by design factors and micro climates. While home investment is influenced by the design and accessibility of site and buildings.
\end{abstract}

Keywords: indoor comfort, lighting, natural ventilation, humidity, acoustic comfort

\begin{abstract}
ABSTRAK
Tuntutan adanya sebuah rumah tidak pernah berhenti karena pertumbuhan penduduk yang selalu meningkat. Pedoman Teknis Pembangunan Rumah Sederhana Sehat yang dikeluarkan oleh Menteri Permukiman dan Prasarana Wilayah (2002) menyatakan bahwa rumah sebagai tempat tinggal yang memenuhi syarat kesehatan dan kenyamanan dipengaruhi aspek pencahayaan, penghawaan, serta suhu udara dan kelembaban dalam ruangan. Adapun variabel yang diangkat terdiri dari pencahayaan alami, penghawaan alami, kelembaban ruang dan kebisingan. Objek dari penelitian ini dibatasi pada dengan luas bangunan maksimal $70 \mathrm{~m}^{2}$ dengan empat sampel rumah yang mempertahankan bentuk rumah asli dari desain pengembang. Dari empat rumah, tiga diantara menunjukkan hubungan bahwa semakin tinggi investasi semakin baik kualitas kenyamanan di dalamnya. Akan tetapi satu diantaranya memperlihatkan pola yang berbeda, hal tersebut dikarenakan nilai investasi yang dipengaruhi oleh nilai aksesibilitas lahan dan bangunan. Penelitian ini pada akhirnya mendapatkan hasil bahwa kenyamanan dalam ruang dipengaruhi oleh faktor desain rumah dan iklim mikro. Sedangkan investasi rumah dipengaruhi oleh desain dan nilai aksesibilitas lahan dan bangunan.
\end{abstract}

Kata kunci: kenyamanan dalam ruang, pencahayaan, penghawaan, kelembaban, kebisingan 


\section{PENDAHULUAN}

Tempat tinggal merupakan kebutuhan wajib bagi manusia, tuntutan adanya sebuah rumah tak berhenti karena pertumbuhan penduduk yang selalu meningkat. Dalam sebuah artikel Kompas edisi 21 Desember, 2017 yang berjudul setiap tahun ada 800.000 unit permintaan rumah baru, Direktur Jenderal Pembiayaan Perumahan Kementerian Pekerjaan Umum dan Perumahan Rakyat (PUPR) Lana Winayanti mengatakan kebutuhan rumah baru ratarata sekitar 800.000 unit per tahun (Prabowo, 2017). Tingkat kebutuhan yang tinggi membuat sulitnya pemenuhan dikarenakan permasalahan ketersediaan lahan. Dalam data Statistik Perumahan Daerah Istimewa Yogyakarta yang dirilis oleh BPS tahun 2017 menunjukkan bahwa laju pertumbuhan penduduk DIY tahun 2016 mencapai 1,13\% dengan penyusutan lahan pertanian sebesar $1,50 \%$. Penyusutan lahan pertanian merupakan salah satu dampak dari perubahan fungsi lahan menjadi rumah. Pada tahun 2015 perkembangan perumahan sederhana berkembang pesat dengan pengajuan perumahan di Sumbawa mencapai 1.976 unit rumah (Ahmad, 2016).

Pedoman Teknis Pembangunan Rumah Sederhana Sehat yang dikeluarkan oleh Menteri Permukiman dan Prasarana Wilayah (2002) menyatakan bahwa rumah sebagai tempat tinggal yang memenuhi syarat kesehatan dan kenyamanan dipengaruhi oleh 3 (tiga) aspek, yaitu pencahayaan, penghawaan, serta suhu udara dan kelembaban dalam ruangan. Sedangakan menurut Satwiko (2009) kenyamanan aspek fisik terdiri dari kenyamanan termal, visual dan audial. Adapun kenyamanan yang diurutkan berdasarkan prioritas adalah kenyamanan termal, kualitas udara dalam ruang,

\section{METODE}

Penelitian ini menggunakan empat objek perumahan berbeda dengan tipe rumah pencahayaan, akustik dan visual (Kapoor dan Tegar, 2018).

Batas kenyamanan merupakan penggunaan skala "temperatur efektif" yang ditentukan dengan percobaan yang mencakup temperatur, kelembaban dan pergerakan udara yang sebenarnya dalam sebuah angka panas atau dingin (Lippsmeir, 1994). Adapun sensasi nyaman bukan sekedar dari aspek fisik dan merupakan reaksi terhadap lingkungan yang sangat dipengaruhi oleh proses kognitif dan perilaku dan membentuk sebuah kebiasaan (Ortiz dkk, 2017).

Penelitian ini bertujuan untuk mengtahui kualitas pencahayaan, penghawaan, kelembaban dan kebisingan pada perumahan berdasarkan standar yang berlaku. Serta untuk mengetahui hubungan biaya investasi dari pembelian rumah dan kenyamanannya pada masing-masing rumah.

Adapun batasan dalam penelitian ini adalah:

1. Batasan dari penelitian ini hanya pada rumah dengan ukuran maksimal $70 \mathrm{~m}^{2}$.

2. Pengukuran pada penelitian ini hanya dilakukan pada bulan Januari sampai dengan Februari 2019.

3. Adapun sampel yang digunakan adalah rumah yang masih mempertahankan bentuk awal dari desain pengembang.

4. Waktu pengukuran mengikuti pedoman SNI yang dilakukan hanya 3 kali dalam satu hari untuk pencahayaan, yaitu pukul 08.00, 12.00 dan 16.00. Sedangkan untuk penghawaan, kelembaban dan kebisingan dilakukan 4 kali, yaitu pada pukul 08.00, 12.00, 16.00 dan 20.00.

5. Pengujian pada masing-masing rumah dilakukan dengan rentang waktu 2 minggu dengan dua kali pengukuran,

sederhana. Luasan objek penelitian berdasar pada Peraturan Pemerintah yang 
menyebutkan bahwa rumah sederhana adalah rumah yang tidak bersusun dengan luas lantai bangunan tidak lebih dari $70^{2}$ meter yang dibangun di atas tanah dengan luas kavling 54-200 meter $^{2}$. Keterbatasan waktu dalam penelitian membuat penelitian ini dilakukan dalam bulan Januari sampai dengan Februari dengan rentang waktu dua minggu.

\section{Metode Pengumpulan Data}

Dalam penelitian ini, adapun data yang akan dikumpulkan akan menggunakan metode sebagai berikut:

1. Observasi Langsung, observasi langsung dilakukan dengan mendatangi perumahan secara langsung. Penelitian mengambil lokasi di Sumbawa sebagai salah satu kota dengan pertumbuhan perumahan sederhana yang sedang berkembang.

2. Pengukuran, pengukuran dilakukan dengan mengukur langsung kondisi variabel kenyamanan seperti kebisingan, pencahayaan, kelembaban dan penghawaan. Pengukuran yang dilakukan menggunakan alat environment meter yang dibantu dengan pengukuran pencahayaan alami dengan

\section{HASIL DAN PEMBAHASAN}

Hasil penelitian dicapai dengan menilai masing-masing variabel kenyamanan pada setiap rumah. Penilaian kenyamanan didapatkan dari pemenuhan standar kondisi eksisting rumah terhadap standar varibel yang berlaku. Penilaian kenyamanan menghasilkan angka dari persentase ruang yang memenuhi syarat. Pada variabel investasi, hasil didapatkan dengan mencari nilai bangunan permeter persegi. Selanjutnya nilai dari variabel investasi dan kenyamanan dimasukkan ke dalam rasio hubungan antara kenyamanan dan investasi tiap rumah.

\section{Pencahayaan}

SNI tentang Konservasi Energi pada Sistem Pencahayaan mengatur tingkat aplikasi Light Meter yang terdapat pada handphone.

3. Kuisioner, kuisioner dilakukan untuk mendapatkan data bersifat subjektif dari masing-masing penghuni rumah. Kuisoner dilakukan dengan mengambil sampel pada penghuni masing-masing tipe rumah.

Dalam penelitian ini variabel yang diteliti adalah:

a. Variabel terikat yang diteliti melalui observasi adalah kondisi eksisiting rumah dengan letak bukaan dan bentuk yang direncanakan oleh masing-masing pengembang.

b. Variabel bebas yang diteliti melalui kuesioner adalah tingkat kenyamanan dalam ruang eksisting yang berasal dari desain pengembang. Variabel dengan kuesioner tersebut antara lain meliputi:

1. Besar pencahayaan alami yang masuk melalui bukaan

2. Penghawaan dari sirkulasi udara melalui bukaan

3. Kebisingan yang ditimbulkan dari posisi bangunan yang berada di dekat jalan dan yang jauh dari jalan

4. Kelembaban dalam ruang

5. Besaran ruang (tinggi dan luas ruang).

pencahayaan rata-rata dalam ruang, tanpa adanya batasan minimum dan maksimum. Sebagai penentu standar minimum, dalam Peraturan Mentri Kesehatan Nomor 1077/MENKES/PER/V/ 2011 tentang Pedoman Penyehatan Udara Dalam Ruang disebutkan bahwa Pencahayaan dalam ruang rumah diusahakan agar sesuai dengan kebutuhan untuk melihat benda sekitar dan membaca dengan nilai minimal 60 Lux. Dalam Rekomendasi Level Cahaya oleh The National Optical Observatory, tingkat cahaya umum yang disarankan bisa mencapai 1000 lux. 
Tabel 1. Nilai Kenyamanan Pencahayaan

\begin{tabular}{|c|c|c|c|c|}
\hline Rumah & $\begin{array}{l}\text { Ruang Memenuhi } \\
\text { Standar }\end{array}$ & $\begin{array}{l}\text { Nilai } \\
\text { (\%) }\end{array}$ & $\begin{array}{l}\text { Ruang yang Tidak } \\
\text { Memenuhi Standar }\end{array}$ & $\begin{array}{l}\text { Nilai } \\
\text { (\%) }\end{array}$ \\
\hline Baiti Jannati & $\begin{array}{l}\text { R. Tamu } \\
\text { K.Tidur } 1 \\
\text { K.Tidur } 2 \\
\text { Dapur }\end{array}$ & 92,7 & Kamar mandi & 7,3 \\
\hline Graha Satelit & $\begin{array}{l}\text { R. Tamu } \\
\text { K.Tidur } \\
\text { Dapur } \\
\text { K. Mandi }\end{array}$ & 100 & - & 0 \\
\hline $\begin{array}{l}\text { Puri Citra } \\
\text { Samawa }\end{array}$ & $\begin{array}{l}\text { R. Tamu } \\
\text { K.Tidur } 1 \\
\text { K.Tidur } 2 \\
\text { Dapur }\end{array}$ & 94 & Kamar mandi & 6 \\
\hline $\begin{array}{l}\text { Bumi } \\
\text { Samawa } \\
\text { Damai }\end{array}$ & $\begin{array}{l}\text { R. Tamu } \\
\text { K.Tidur } 1 \\
\text { K.Tidur } 2 \\
\text { Dapur } \\
\text { K. Mandi }\end{array}$ & 100 & - & 0 \\
\hline
\end{tabular}

Berdasarkan penilaian dari Tabel 1, diketahui bahwa rumah Graha Satelit dan Bumi Samawa Damai memiliki nilai yang sempurna. Dibandingkan Baiti Jannati dan Puri Citra Samawa, Bumi Samawa Damai dan Graha Satelit memiliki keunggulan karena beberapa faktor, yaitu luasan lubang cahaya yang lebih besar dan warna permukaan dinding yang berwarna putih. Permukaan putih memantulkan semua panjang gelombang (Meilani, 2013). Warna putih bersifat memantulkan cahaya membuat ruangan memiliki intensitas cahaya yang tinggi dibandingkan penggunaan warna dasar dinding lainnya. Pencahayaan pada rumah Baiti Jannati dan Puri Citra Samawa tidak memenuhi standar pada kamar mandi. Kamar mandi adalah ruang paling sedikit mendapatkan cahaya (Ashadi dkk, 2015). Bebarapa kemungkinan penyebab kondisi pencahayaan yang kurang adalah:

\section{Luasan lubang cahaya kecil}

Luasan lubang cahaya yang kecil yang menyebabkan sedikit cahaya yang masuk. Orientasi jendela yang menghadap Selatan dan Utara cenderung mendapatkan cahaya yang lebih kecil dibandingkan dengan orientasi Timur dan Barat. Akan tetapi, orientasi Timur dan Barat akan menyebabkan terpaparnya dinding yang membuat ruang lebih panas. Bukaan Timur dan Barat sekecil mungkin untuk mengurangi panas matahari ke dalam bangunan (Latifah, 2013). Jika lubang cahaya pada dinding Timur dan Barat diperbesar maka dapat ditambahkan sun shading untuk memantullkan sinar matahari agar mendapatkan cahaya yang jatuh lebih lembut. Untuk mengontrol besaran bukaan angin, kisaran optimal WFR (Window to Floor Ratio) adalah $15 \%$ sampai $24 \%$ yang dapat juga mengontrol silau dan panas berlebih (Vaisi dan Kharvari, 2019). WFR (Window to Floor Ratio) dan dimensi overhang adalah salah satu parameter yang paling berpengaruh terhadap tingkat pencahayaan (Maltais dan Gosselin, 2017).

\section{Warna permukaan dinding}

Menurut Latifah (2013), gelap terangnya warna permukaan pada dinding dapat mempengaruhi pantulan dan resapan cahaya. Semakin terang warna dinding, maka semakin baik dalam memantulkan cahaya. Warna putih pada permukaan dinding rumah Puri Citra Samawa bersifat memantulkan cahaya, sehingga ruang menjadi lebih terang dibandingkan pada rumah lainnya dengan warna yang lebih gelap.

\section{Posisi lubang cahaya}

Posisi lubang cahaya adalah salah satu variabel yang berpengaruh pada pencahayaan siang hari (Latifah, 2015). Selain luasan lubang cahaya, posisi lubang cahaya akan mempengaruhi pemerataaan cahaya yang masuk. Posisi lubang cahaya 
atau jendela yang terlalu pinggir membuat cahaya hanya dapat memenuhi kebutuhan sebagian kecil dari luasan ruang.

\section{Penghawaan}

SNI merupakan salah satu rujukan dalam standar pemenuhan kenyamanan penghawaan berdasarkan kondisi alam Indonesia. Penelitian ini menggunakan SNI 03-6572-2001 mengenai Tata Cara Perancangan Sistem Ventilasi dan
Pengkondisian Udara pada Bangunan Gedung sebagai acuan untuk mencapai kenyamanan penghawaan dan kelembaban rumah. Pada standar yang dikeluarkan oleh SNI, diketahui bahwa standar suhu nyaman yaitu antara rentang $20,5-22,8^{\circ} \mathrm{C}$, nyaman optimal $22,8^{\circ} \mathrm{C},-25,8^{\circ} \mathrm{C}$, dan hampir nyaman $25,8 \stackrel{\circ}{\circ}$, $-27,1^{\circ} \mathrm{C}$. Untuk untuk kondisi yang tidak memiliki pergerakan angin. Frick (2007) mengeluarkan grafik comfort zone yang dapat dijadikan acuan penentu standar angin dan suhu pada ruang.

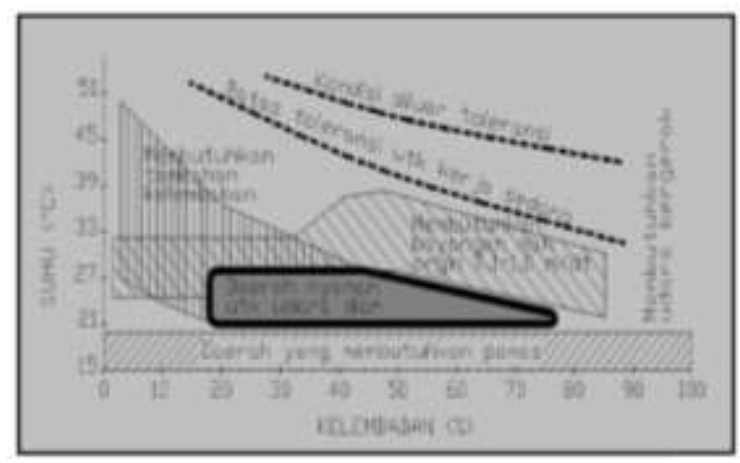

Gambar 1. Daerah Nyaman (Comfort Zone)

(Sumber: Frick, 2007)

Berdasarkan hasil analisa penghawaan pada Tabel 2, diketahui bahwa rumah yang masuk katagori nyaman SNI hanya Graha Satelit dan Puri Citra Samawa. Ruang yang masuk ke dalam katagori nyaman memiliki kriteria yang sama, yaitu:

1. Orientasi bukaan yang menghadap arah datangnya angin dengan luas bukaan angin diatas 5\% (Standar Nasional Indonesia, 2001) serta bukaan yang memiliki sistem ventilasi silang dengan arah ventilasi yang berhadapan. Secara teori, ventilasi silang menghasilkan peningkatan kecepatan udara dan turunnya suhu ruangan.

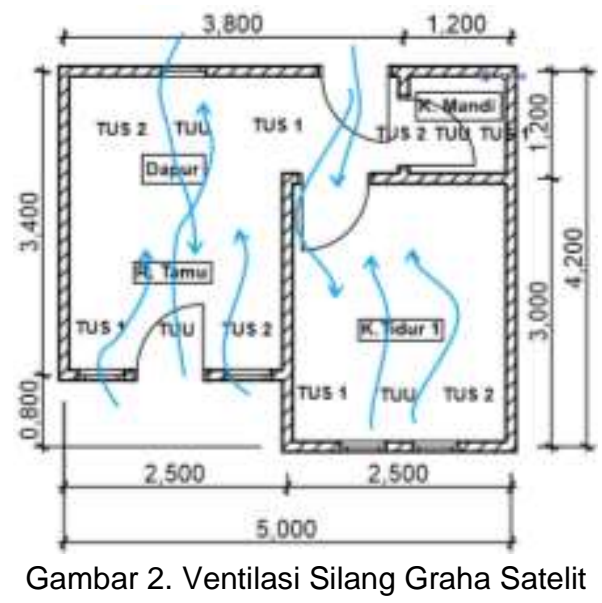




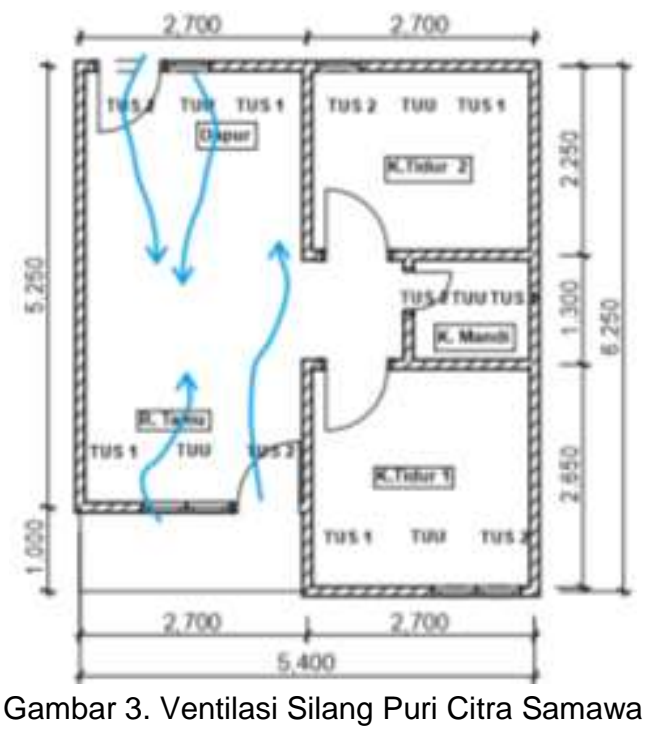

2. Graha Satelit dan Puri Citra Samawa memiliki ketinggian ruang yang lebih tinggi dibandingkan dengan Baiti Jannati dan Bumi Samawa Damai. Graha Satelit memiliki tinggi ruang 3,8 meter dan Puri Citra Samawa 3,4 meter sedangkan pada Baiti Jannati hanya 3 meter dan Bumi Samawa Damai 2,75 meter. Ketinggian ruang berpengaruh pada pergerakan udara dalam ruang, semakin rendah suatu ruang, maka pergerakan udara di dalamnya semakin terbatas, begitu pula sebaliknya. Langitlangit yang lebih tinggi mendapatkan udara dan suhu yang lebih dingin (Aflaki dkk, 2014).

Tabel 2. Nilai Kenyamanan Penghawaan Ruang

\begin{tabular}{|c|c|c|c|c|}
\hline Rumah & $\begin{array}{l}\text { Ruang Memenuhi } \\
\text { Standar }\end{array}$ & $\begin{array}{l}\text { Nilai } \\
(\%) \\
\end{array}$ & $\begin{array}{l}\text { Ruang yang Tidak } \\
\text { Memenuhi Standar }\end{array}$ & $\begin{array}{l}\text { Nilai } \\
(\%) \\
\end{array}$ \\
\hline Baiti Jannati & - & 0 & $\begin{array}{l}\text { R. Tamu } \\
\text { K.Tidur } 1 \\
\text { K.Tidur } 2 \\
\text { Dapur } \\
\text { K. Mandi }\end{array}$ & 100 \\
\hline Graha Satelit & $\begin{array}{l}\text { R. Tamu } \\
\text { K.Tidur } \\
\text { Dapur }\end{array}$ & 93 & K. Mandi & 7 \\
\hline $\begin{array}{l}\text { Puri Citra } \\
\text { Samawa }\end{array}$ & $\begin{array}{l}\text { R. Tamu } \\
\text { Dapur }\end{array}$ & 44,3 & $\begin{array}{l}\text { K.Tidur } 1 \\
\text { K.Tidur } 2 \\
\text { Kamar mandi }\end{array}$ & 55,7 \\
\hline $\begin{array}{l}\text { Bumi } \\
\text { Samawa } \\
\text { Damai }\end{array}$ & - & 0 & $\begin{array}{l}\text { R. Tamu } \\
\text { K.Tidur } 1 \\
\text { K.Tidur } 2 \\
\text { Dapur } \\
\text { K. Mandi }\end{array}$ & 100 \\
\hline
\end{tabular}

Selain pada dua kesamaan tersebut, Graha Satelit memiliki kelebihan dibandingkan rumah lainnya. Rumah pada Graha Satelit tidak berhimpitan dan memiliki jarak antar rumah. Dengan kondisi tersebut, rumah Graha Satelit mudah menerima angin dan cahaya sehingga kondisi dalam ruang lebih nyaman. 


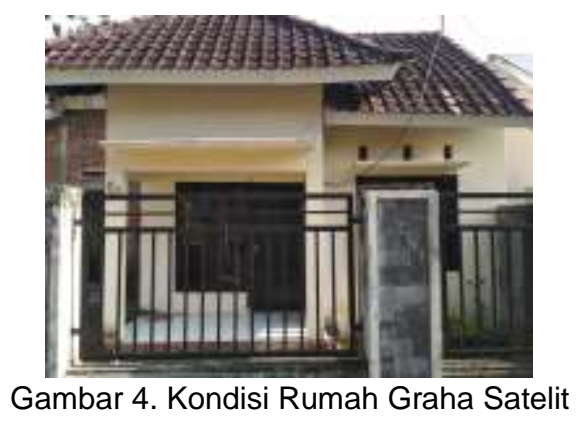

Rumah Baiti Jannati dan Bumi Samawa Damai tidak termasuk nyaman dikarenakan suhu yang tinggi tidak diimbangi dengan angin yang masuk ke dalam ruang. Suhu rata-rata Baiti Jannati adalah $30,4{ }^{\circ} \mathrm{C}$, sedangkan Bumi Smawa Damai $31,4{ }^{\circ} \mathrm{C}$. Dalam penelitiannya Djamila dkk (2013) mendapati bahwa suhu yang masuk dalam katagori kenyamanan mendekati $30^{\circ} \mathrm{C}$.

Rumah Baiti Jannati memiliki orientasi yang berbeda dari arah datangnya angin. Hal tersebut membuat ruang tidak menerima angin dari luar. Udara yang tidak bergerak dalam ruangan tertutup akan menyebabkan pengguna ruangan merasa kaku ataupun berkeringat (ASHRAE, 1989). Pada Bumi Samawa Damai bukaan telah menghadap arah angin, akan tetapi besaran ruang yang kecil dan tinggi langit-langit rendah membuat ruang menjadi lebih panas dan gerah (Sugini, 2011). Langit-langit ruang yang rendah akan meningkatkan radiasi panas dalam ruang. Ketinggian langit-langit ruang yang rendah dan ruang yang tinggi memiliki perbedaan suhu mencapai $1,54{ }^{\circ} \mathrm{C}$, dengan kondisi ruang yang tinggi memiliki suhu yang lebih nyaman (Aflaki dkk, 2014). Selain ketinggian ruang, konfigurasi langitlangit memiliki efek tertentu pada aliran udara dalam ruangan dan laju aliran ventilasi (Nguyen dan Reiter, 2011).

Suhu nyaman sulit untuk dicapai hanya dengan menggunakan ventilasi alami dan orientasi bangunan, perangkat naungan yang tidak memadai, dan bahan bangunan adalah beberapa faktor yang menyebabkan kondisi panas (Alfata dkk, 2015). Selanjutnya penelitian di Malaysia dan mendapatkan hasil bahwa suhu dalam ruang eksisting lebih tinggi dari standar yang dikeluarkan pemerintah (Jamaludin dkk, 2015). Dalam hal perilaku pengguna bangunan dalam menghadapi panas, Indonesia dan Jepang memilih cara dengan makan dan minum dingin, sedangkan Malaysia dengan menggunakan air conditioning (Damiati dkk, 2016).

\section{Kelembaban}

Kelembaban merupakan salah satu faktor penting untuk mendukung kenyamanan penghawaan dalam ruang. Pengukuran kelembaban menghasilkan ruang-ruang yang tidak memenuhi standar, karena nilai kelembaban yang tinggi. Tabel 3 memperlihatkan hasil penilaian pada rumah-rumah terhadap nilai kelembaban di dalamnya.

Tabel 3. Nilai Kenyamanan Kelembaban Ruang

\begin{tabular}{|c|c|c|c|c|}
\hline Rumah & $\begin{array}{l}\text { Ruang Memenuhi } \\
\text { Standar }\end{array}$ & $\begin{array}{l}\text { Nilai } \\
\text { (\%) }\end{array}$ & $\begin{array}{l}\text { Ruang yang Tidak } \\
\text { Memenuhi Standar }\end{array}$ & $\begin{array}{c}\text { Nilai } \\
(\%)\end{array}$ \\
\hline Baiti Jannati & - & 0 & $\begin{array}{l}\text { R. Tamu } \\
\text { K.Tidur } 1 \\
\text { K.Tidur } 2 \\
\text { Dapur } \\
\text { K. Mandi }\end{array}$ & 100 \\
\hline Graha Satelit & - & 0 & $\begin{array}{l}\text { R. Tamu } \\
\text { K.Tidur } \\
\text { Dapur } \\
\text { K. Mandi }\end{array}$ & 100 \\
\hline
\end{tabular}


Tabel 3. Nilai Kenyamanan Kelembaban Ruang

\begin{tabular}{lcclc}
\hline \multicolumn{1}{c}{ Rumah } & $\begin{array}{c}\text { Ruang Memenuhi } \\
\text { Standar }\end{array}$ & Nilai & $\begin{array}{l}\text { Ruang yang Tidak } \\
\text { Memenuhi Standar }\end{array}$ & $\begin{array}{c}\text { Nilai } \\
(\%)\end{array}$ \\
\hline Puri Citra & - & $(\%)$ & R. Tamu & 100 \\
Samawa & & $\begin{array}{l}\text { K.Tidur 1 } \\
\text { K.Tidur 2 } \\
\text { Dapur }\end{array}$ & \\
& & & $\begin{array}{l}\text { K. Mandi } \\
\text { R. Tamu }\end{array}$ & \\
Bumi & 0 & $\begin{array}{l}\text { K.Tidur 1 } \\
\text { K.Tidur 2 } \\
\text { Samawa }\end{array}$ & & 100 \\
Damai & - & Kapur Mandi & \\
& & & \\
\hline
\end{tabular}

Nilai kelembaban pada setiap rumah 0 dikarenakan tidak ada satupun rumah yang memenuhi standar kelembaban yang di syaratkan SNI yang disebabkan oleh nilai kelembaban pada masing-masing rumah yang tinggi. Kelembaban pada setiap rumah tinggi dapat disebabkan oleh beberapa faktor, salah satunya adalah iklim setempat. Beberapa hal yang menyebabkan kelembaban (Fatma, 2018) adalah ketersediaan air dan pergerakan angin. Daerah yang memiliki ketersediaan air yang banyak akan memiliki tingkat kelembaban udara yang tinggi. Lokasi air tanah yang dangkal dapat mempengaruhi kondisi kelembaban bangunan di atasnya. Sedangkan pergerakan angin juga mempengaruhi tingkat kelembaban udara (Kartika, 2003). Hal tersebut karena angin dapat mempengaruhi proses penguapan. Kondisi eksisting rumah tidak dapat menerima angin karena orientasi bukaan yang tidak sama dengan arah angin merupakan salah satu penyebab yang membuat rumah lebih lembab.

Selain faktor alam sekitar, faktor pondasi juga mempengaruhi kelembaban. Tanah urug yang digunakan untuk mengisi urugan pada pondasi menyebabkan kelembaban terserap dan naik ke atas. Pondasi yang lembab merupakan potensi dasar dari kelembaban dalam ruang (Wolde dan Pilon, 2007).

Dalam penelitian Santoso (2012), kenyamanan termal di daerah beriklim tropis lembab untuk bangunan (indoor) dengan menggunakan penghawaan alami atau ventilasi sulit untuk menjangkau standar kenyamanan internasional ASHRAE 55-92. Hasil dari penelitian Santoso sejalan dengan penelitian ini. Meskipun penelitian ini menggunakan standar SNI, akan tetapi SNI menggunakan ASHRAE sebagai acuan. Djamila dkk (2013) mengindikasikan bahwa grafik standar yang dikeluarkan oleh ASHRAE lebih sesuai untuk ruang dengan penggunaan air conditioning dibandingkan ruang dengan ventilasi alami.

\section{Kebisingan}

Selain standar kenyamanan untuk penghawaan dan pencahayaan, juga terdapat kenyamanan dari kebisingan yang diatur dalam Keputusan Menteri Lingkungan Hidup Nomor 48 Tahun 1996 tentang baku tingkat kebisingan untuk tingkat kebisingan yang dapat diterima oleh suatu perumahan adalah dan permukiman 55 dBA. Dari perspektif pengendalian kebisingan, alasan utama kebisingan adalah jarak bangunan dari jalan, jarak satu sama lain bangunan dan refleksi dari permukaan bangunan (Gedik dkk, 2017). Penelitian kebisingan dilakukan oleh Setiawan (2010) mendapatkan hasil kebisingan tertinggi sebesar 69,64 dB dari sumber bising sejauh 80 meter dengan sumber kebisingan kendaraan bermotor. Puri Citra Samawa merupakan rumah dengan jarak paling dekat dengan jalan yaitu $92 \mathrm{~m}$ dan memiliki nilai kebisingan yang berada di bawah $55 \mathrm{~dB}$. Selain Puri Citra Samawa, tiga rumah lainnya juga memiliki nilai rata-rata di bawah $55 \mathrm{~dB}$. Rendahnya kebisingan pada semua rumah dikarenakan tingkat lalu lintas yang rendah 
pada disekitar perumahan dan kondisi

lingkungan sekitar yang masih sepi.

Tabel 4. Nilai Kenyamanan Kebisingan Ruang

\begin{tabular}{|c|c|c|c|c|}
\hline Rumah & $\begin{array}{l}\text { Ruang Memenuhi } \\
\text { Standar }\end{array}$ & $\begin{array}{l}\text { Nilai } \\
\text { (\%) }\end{array}$ & $\begin{array}{l}\text { Ruang yang Tidak } \\
\text { Memenuhi Standar }\end{array}$ & $\begin{array}{l}\text { Nilai } \\
\text { (\%) }\end{array}$ \\
\hline Baiti Jannati & $\begin{array}{l}\text { R. Tamu } \\
\text { K.Tidur } 1 \\
\text { K.Tidur } 2 \\
\text { Dapur } \\
\text { K. Mandi }\end{array}$ & 100 & - & 0 \\
\hline $\begin{array}{l}\text { Graha } \\
\text { Satelit }\end{array}$ & $\begin{array}{l}\text { R. Tamu } \\
\text { K.Tidur } \\
\text { Dapur } \\
\text { K. Mandi }\end{array}$ & 100 & - & 0 \\
\hline $\begin{array}{l}\text { Puri Citra } \\
\text { Samawa }\end{array}$ & $\begin{array}{l}\text { R. Tamu } \\
\text { K.Tidur } 1 \\
\text { K.Tidur } 2 \\
\text { Dapur } \\
\text { K. Mandi }\end{array}$ & 100 & - & 0 \\
\hline $\begin{array}{l}\text { Bumi } \\
\text { Samawa } \\
\text { Damai }\end{array}$ & $\begin{array}{l}\text { R. Tamu } \\
\text { K.Tidur } 1 \\
\text { K.Tidur } 2 \\
\text { Dapur } \\
\text { K. Mandi }\end{array}$ & 100 & - & 0 \\
\hline
\end{tabular}

\section{Kenyamanan Rumah}

Hasil pencapaian kenyamanan dari empat variabel, Graha Satelit dan Puri Citra Samawa memenuhi tiga variabel, diantaranya pencahayaan, penghawaan dan kebisingan. Pada rumah Baiti Jannati dan Bumi Samawa Damai, variabel kenyamanan yang dapat dicapai hanya pada pencahayaan dan kebisingan. Secara garis besar, nilai kelembaban 0 pada setiap rumah dikarenakan faktor iklim dan lingkungan setempat dan faktor desain pondasi rumah. Selain faktor tersebut, telah disebutkan sebelumnya bahwa standar SNI sulit dicapai karena acuan menggunakan ASHRAE, sama seperti penelitian sebelumnya oleh Santoso (2012).

Dari hasil nilai kenyamanan yang telah di jabarkan, selanjutnya dirangkum dan dimasukkan ke dalam Tabel 5. Dari hasil variabel kenyamanan, diketahui bahwa rumah dengan tingkat kenyamanan paling tinggi adalah Graha Satelit, diikuti oleh Puri Citra Samawa, Bumi Samawa
Damai dan Baiti Jannati. Dari keempat rumah, variabel yang paling tidak bisa dicapai adalah kelembabanSelain kelembaban, permasalahan lainnya adalah penghawaan. Penghawaan menjadi kurang nyaman karena suhu yang tinggi tidak diikuti dengan nilai angin yang masuk dalam ruang. Dari empat objek penelitian, tiga diantaranya yaitu Graha Satelit, Puri Citra Samawa dan Bumi Samawa Damai memiliki orientasi yang sesuai dengan arah angin. Berbeda dari Puri Citra Samawa dan Bumi Samawa Damai, Graha Satelit mendapatkan keuntungan karena perumahan yang berada di lereng bukit. Kondisi tersebut berakibat pada tingkat angin yang tinggi karena aliran angin yang bergerak dari tempat bersuhu panas mengalir ketempat bersuhu rendah. Selanjutnya, nilai kenyamanan yang didapatkan dapat dimasukkan ke dalam Gambar 5 yang memperlihatkan perbandingan nilai antar rumah. 
Tabel 4. Nilai Kenyamanan Rumah

\begin{tabular}{lcccc}
\hline $\begin{array}{c}\text { Rumah } \\
\text { Variabel }\end{array}$ & Baiti Jannati & $\begin{array}{c}\text { Graha Satelit } \\
\text { Persentase Kenyamanan (\%) }\end{array}$ & $\begin{array}{c}\text { Puri Citra } \\
\text { Samawa }\end{array}$ & $\begin{array}{c}\text { Bumi Samawa } \\
\text { Damai }\end{array}$ \\
\hline Pencahayaan & 92,7 & 100 & 94 & 100 \\
Penghawaaan & 0 & 93 & 44,3 & 0 \\
Kelembaban & 0 & 0 & 0 & 0 \\
Kebisingan & 100 & 100 & 100 & 100 \\
Rata-rata & 48,2 & 73,3 & 59,6 & 50,0 \\
\hline
\end{tabular}

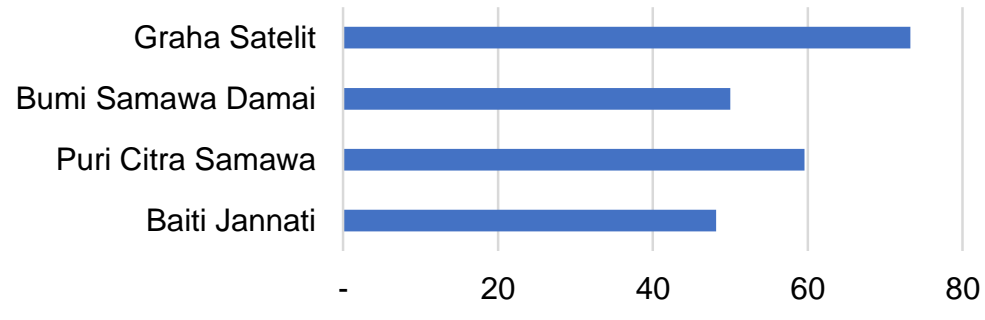

Gambar 5. Perbandingan Nilai Kenyamanan Antar Rumah

Setelah melakukan penilaian terhadap kenyamanan empat rumah, terdapat beberapa hal yang dapat disarankan untuk meningkatkan kenyamanan rumah. Adapun hal yang dapat dilakukan adalah:

1. Pencahayaan

Pencahayaan yang tidak memenuhi standar pada kamar mandi Baiti Jannati dan Puri Citra Samawa dapat tingkatkan dengan memperbesar lubang cahaya kamar mandi. Sebagai ruang yang memiliki tingkat privasi yang tinggi, ventilasi cahaya kamar mandi dapat menggunakan material block glass dengan ketinggian di atas 2,2 meter. Bagi Puri Citra Samawa yang tidak memiliki bukaan cahaya, pencahayaan dapat ditambahkan dengan menggunakan genteng kaca sebagai pencahayaan alami dari atas (skylight).

2. Penghawaan

Penghawaan Baiti Jannati yang tidak termasuk katagori nyamanan memerlukan angin untuk membuat udara panas dalam rumah keluar. Untuk mendapatkan angin, Baiti Jannati perlu memberikan ventilasi tambahan pada bagian Timur dan Barat bangunan. Bagian Timur dan Barat bangunan cenderung mendapatkan radiasi sinar matahari yang besar, oleh karena itu ventilasi dapat menggunakan jenis jendela sirip agar angin dapat masuk, akan tetapi dapat mengurangi radiasi. Selain dengan menggunakan jenis jendela sisir, hal yang dapat digunakan untuk mengurangi radiasi adalah dengan menambahkan sun shading. Penghawaan pada Bumi Samawa Damai dapat ditingkatkan dengan menambahkan tinggi bangunan dan mengurangi sekat dalam rumah.

3. Kelembaban

Kelembaban pada rumah dapat dikurangi dengan menggunakan sistem ventilasi silang. Sistem ventilasi silang sebaiknya memiliki bukaan angin yang berhadapan pada kedua sisi. Santoso (2012) menyarankan perlunya dilakukan kontrol atau tindakan adaptif dari penghuni diantaranya dengan mengatur sistim ventilasi, mengatur sirkulasi angin secara mekanik.

4. Kebisingan

Semua rumah mendapatkan kenyamanan yang memenuhi standar pada varibel kebisingan. Akan tetapi 
untuk memaksimalkan kenyamanan audial pemilik rumah, hal yang dapat dilakukan adalah dengan mengganti material permukaan halaman dengan rumput. Material eksisting permukaan halaman rumah pada masing-masing rumah menggunakan paving block. Paving block dapat memanatulkan bunyi, sedengkan tanaman rumput bersifat lebih meredam bunyi. Barier kebisingin akan lebih efektif dengan ditingkatkannya ketebalan, tinggi dan kerapatan tanaman (Grey dan Denake, 1978).

\section{Nilai Investasi Rumah}

Nilai investasi yang dimaksud dalam penelitian adalah harga beli rumah dan tanah yang dilakukan oleh pemilik rumah. Rumah pada penelitian memiliki luasan yang berbeda. Nilai investasi rumah dihitung dengan cara mengetahui harga rumah permeter persegi $\left(\mathrm{m}^{2}\right)$. Harga rumah didapatkan dengan mengetahui nilai tanah yang nantinya akan dikurangi dari harga beli rumah. Karena tahun pembangunan rumah yang berbeda-beda, penulis menggunakan dasar dari inflasi untuk menentukan nilai masa lalu. Nilai tanah didapatkan dari situs BPN, yang kemudian didapatkan nilai sebagaimana yang ditampilkan oleh Tabel 6.

Tabel 4. Nilai Kenyamanan Rumah

\begin{tabular}{lcccc}
\hline Rumah & Baiti Jannati & Graha Satelit & Puri Citra Samawa & $\begin{array}{c}\text { Bumi Samawa } \\
\text { Damai } \\
\text { Harga }\end{array}$ \\
& $\mathbf{2 0 1 6}$ & $\mathbf{2 0 1 1}$ & $\mathbf{2 0 1 7}$ & $\mathbf{3 0 / 1 2 0}$ \\
& $\mathbf{3 6 / 1 2 0}$ & $\mathbf{2 1 / 1 0 0}$ & $\mathbf{3 2 / 1 0 0}$ & \\
\hline Harga Beli & 148.500 .000 & 120.000 .000 & 133.500 .000 & 133.500 .000 \\
Harga Tanah & 62.051 .190 & 46.588 .453 & 59.427 .000 & 66.909 .888 \\
Harga Tanah $\left(\mathrm{m}^{2}\right)$ & 517.093 & 465.885 & 594.270 & 557.582 \\
Harga Rumah & 86.448 .810 & 73.411 .547 & 74.073 .000 & 66.590 .112 \\
Harga Tanah $\left(\mathrm{m}^{2}\right)$ & 2.776 .333 & 3.127 .619 & 2.774 .063 & 2.837 .200 \\
\hline
\end{tabular}

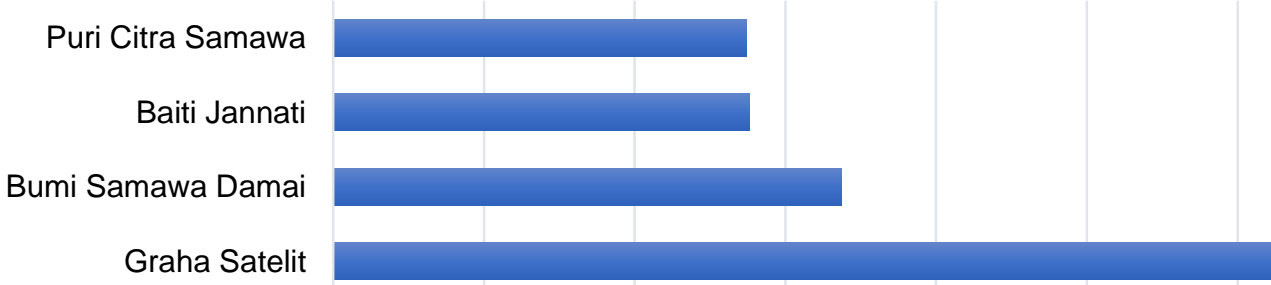

2,500,000 2,600,000 2,700,000 2,800,000 2,900,000 3,000,000 3,100,000 3,200,000

Gambar 6. Perbandingan Harga Investasi Rumah

Empat rumah yang dijadikan sampel memiliki luasan dan harga yang berbeda, dari keempat objek, Graha Satelit adalah rumah dengan harga yang paling mahal diantara yang lain, hal tersebut karena Graha Satelit memiliki posisi paling startegis terhadap jalan dan kota. Selanjutnya harga diikuti oleh Bumi Samawa Damai, Puri Citra Samawa dan terakhir Baiti Jannati.

Graha Satelit memiliki nilai rumah paling tinggi diimbangi dengan kualitas bangunan dan desainnya. Diantara tiga bangunan lainnya, Graha Satelit memiliki desain bangunan yang memiliki ventilasi silang paling baik. Ventilasi silang pada Graha Satelit dipengaruhi oleh desain ruang yang memiliki orientasi bukaan menghadap angin serta langit-langit rumah yang tinggi.

Rumah Puri Citra Samawa memiliki harga paling murah diantara lainnya. Jika ditinjau dari harga beli, Puri Citara Samawa dan Bumi Samawa Damai berada diharga yang sama. Puri Citra Samawa lebih murah dikarenakan luas dan tinggi bangunan yang 
lebih besar dibandingkan dengan Bumi Samawa Damai. Selain dari faktor harga beli, faktor aksesibilitas Puri Citra Samawa paling jauh dengan kota dibandingkan dengan tiga rumah lainnya. Aksesibilitas bangunan dan tanah terhadap kota akan menentukan nilainya (Fahira dkk, 2010). Semakin dekat dan mudah akses maka nilai jual semakin tinggi, begitu pula sebaliknya. Gambar 7 memperlihatkan posisi masing- masing rumah terhadap kota. Dari gambar diketahui bahwa Bumi Samawa Damai lebih dekat, akan tetapi Graha Satelit paling stategis dan memiliki aksesibilitas paling baik karena lokasi yang berdekatan dengan jalan. Posisi Graha Satelit yang strategis berbanding lurus dengan nilai lahan dan bangunan yang lebih besar dibandingkan rumah lainnya.

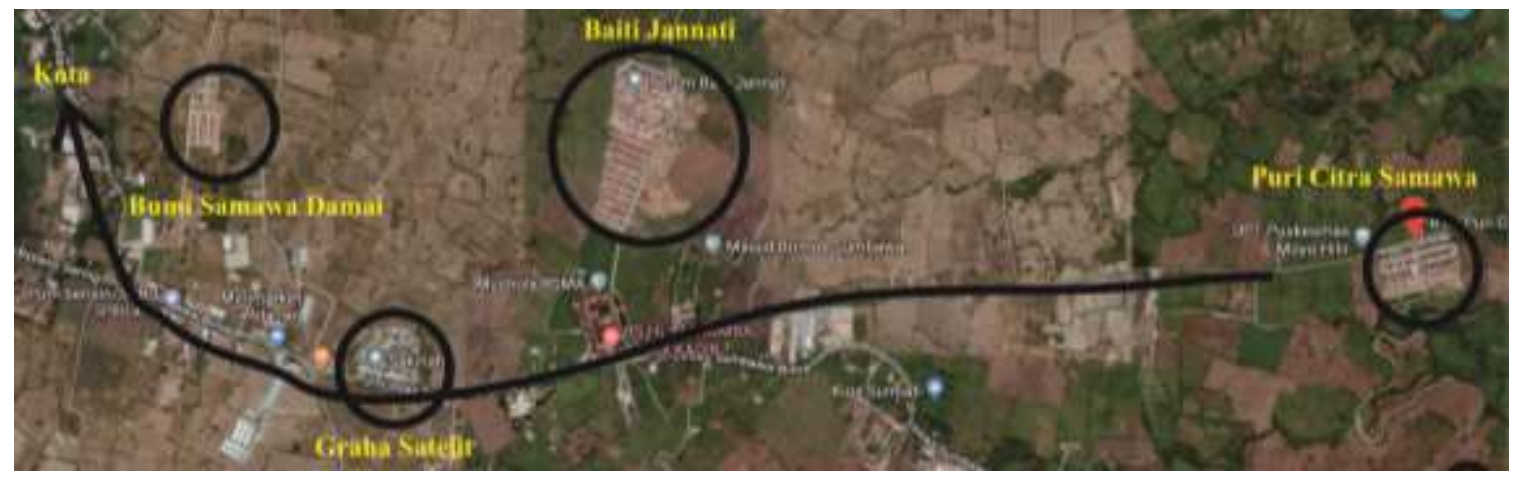

Gambar 7. Posisi Rumah Terhadap Kota

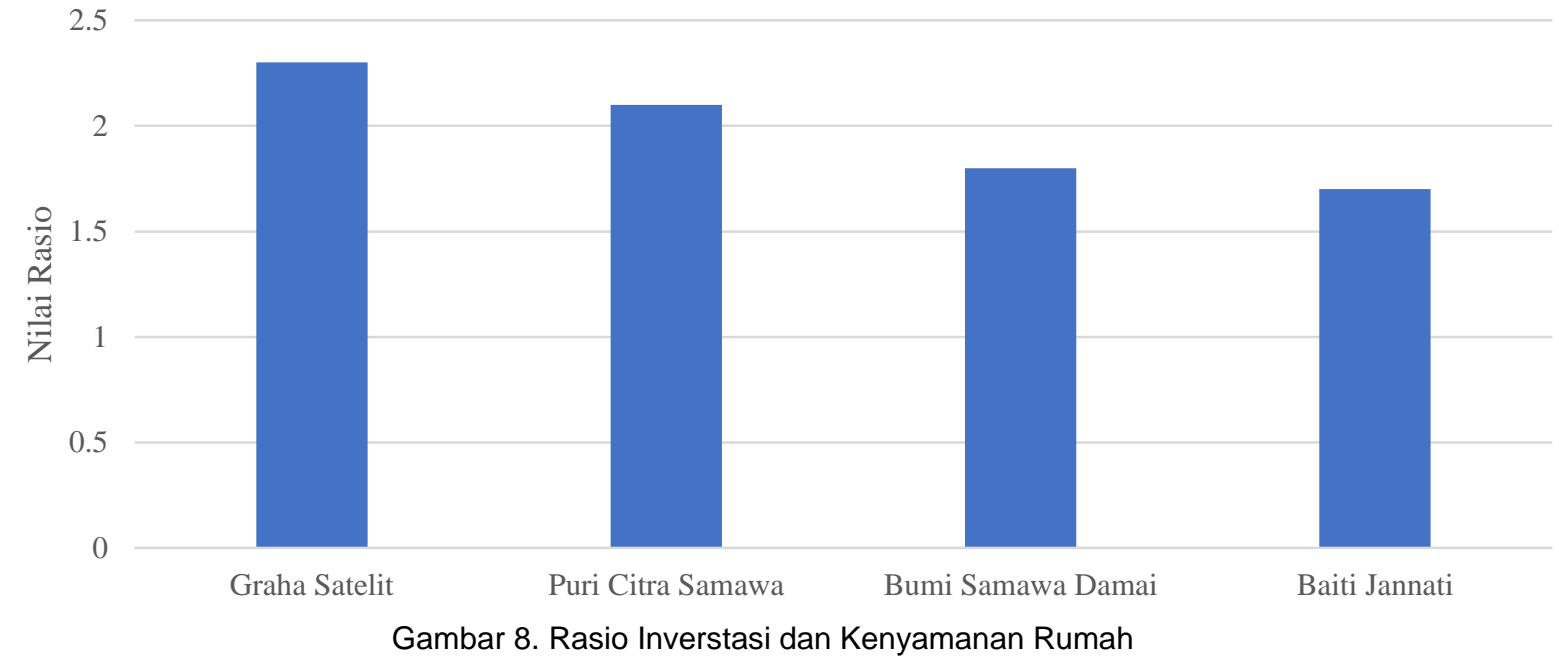

\section{Perbandingan Nilai Kenyamanan dan Investasi pada Rumah}

Berdasarkan analisis dan penjabaran sebelumnya telah didapatkan nilai kenyamanan dan investasi dari masingmasing rumah. Selanjutnya untuk mengetahui hubungan antara investasi dan kenyaman pada masing-masing rumah, akhir hubungan. Gambar grafik 8 memperlihatkan rasio kenyamanan dan investasi pada setiap rumah.nilai kenyamanan dan investasi dimasukkan kedalam rasio yang memperlihatkan nilai akhir hubungan.

Rasio di atas menampilkan hubungan kenyamanan dan investasi yang didapatkan dari nilai kenyamanan yang dibagi nilai investasi rumah. Dari gambar grafik 8 di atas, diketahui bahwa nilai rasio paling tinggi adalah rumah Graha Satelit, di ikuti oleh Puri Citra Samawa, Bumi Samawa Damai dan terakhir Baiti Jannati. Dari rasio tersebut diketahui bahwa Graha Satelit merupakan rumah yang paling tinggi tingkat kenyamanan yang berbanding lurus dengan 
harga investasinya. Pada Graha Satelit, investasi rumah yang tinggi didukung dengan desain yang dibutuhkan untuk kenyaman ruang di dalam ruang.

Puri Citra Samawa memiliki tingkat kenyamanan kedua setelah Graha Satelit, akan tetapi memiliki nilai investasi paling sedikit diantara rumah lainnya. Dalam hal ini nilai investasi yang kecil tidak mempengaruhi tingkat kenyamanan rumah. Karena ada beberapa faktor pendukung lainnya yang membuat mahal murahnya suatu perumahan. Faktor desain bangunan merupakan faktor yang berperan penting dalam nilai yang akan didapatkan bangunan terhadap kenyamanannya. Pada kasus Puri Citra Samawa, bukan desain yang membuat nilai investasi rendah, akan tetapi nilai aksesibilitas bangunan dan lahannya.

Dua rumah terakhir, yaitu Baiti Jannati dan Bumi Samawa Damai memiliki nilai rasio tidak jauh berbada. Jika dinilai dari faktor kenyamanan, Bumi Citra Samawa unggul

\section{SIMPULAN}

1. Pencahayaan pada setiap rumah memiliki nilai yang paling tinggi dibandingkan varibel kenyamanan lainnya. Dari nilai kenyamanan pencahayaan empat rumah, rumah Graha Satelit dan Bumi Samawa Damai memiliki persentase ruang yang mendapatkan cahaya paling tinggi dari rumah lainnya. faktor yang mempengaruhi pencahayan pada keempat rumah yang diteliti dipengaruhi oleh bukaan cahaya, dimensi ruang, material interior ruang (warna permukaan dinding ruang). Ketiga faktor tersebut berasal dari faktor internal rumah atau dari aspek desain rumah tersebut.

2. Ruang yang memenuhi kenyamanan penghawaan dipengaruhi oleh tinggi langit-langit ruang, adanya sistem ventilasi silang, jarak antar bangunan serta orientasi ventilasi angin. Graha Satelit menjadi rumah dengan kualitas penghawaan paling baik karena memiliki semua faktor pendukung tersebut. Selain dari faktor desain, kualitas penghawaan karena pencahayaannya yang baik. Salah satu faktor pendukungnya karena warna permukaan dinding putih dan luasan ruang yang kecil sehingga setiap sisi ruang dapat dijangkau cahaya. Disisi lain, ruang kecil dan langit-langit rendah mengakibatkan ruang mendapatkan radiasi panas yang lebih tinggi sehingga kenyamanan penghawaan semakin berkurang. Berbeda dari permasalahan Bumi Citra Samawa, Baiti Jannati memiliki permasalahan pada desain bangunan, khususnya ventilasi ruang. Ventilasi pada Baiti Jannati lebih kecil dibandingkan dengan Bumi Samawa Damai, akibatnya salah satu ruang yaitu kamar mandi tidak mendapatkan pencahayaan yang cukup. Selain pada pencahayaan, ventilasi Baiti Jannati memiliki orientasi berbeda dengan arah datangnya angin, hal tersebut membuat ruang tidak menerima angin dari lingkungan luar. Baiti jannati lebih murah dan memiliki nilai kenyamanan lebih kecil dibandingkan dengan Bumi Samawa Dama

pada keempat rumah sulit dicapai karena kondisi suhu wilayah Sumbawa yang panas dan faktor iklim mikro setempat.

3. Kelembaban pada keempat rumah memiliki kualitas kelembaban yang tinggi dan tidak masuk dalam persyaratan yang di tentukan oleh SNI.

4. Kualitas kebisingan yang baik disebabkan lokasi yang jauh dari jalan dan kondisi lalu lintas yang tidak terlalu ramai. Selain itu, kebisingan yang berasal dari lingkungan rumah masih termasuk dalam kebisingan yang tidak mengganggu.

5. Berdasarkan nilai semua variabel kenyamanan, disimpulkan bahwa rumah yang memiliki nilai kenyamanan paling tinggi adalah Graha Satelit, diikuti oleh Puri Citra Samawa, Bumi Samawa Damai dan Baiti Jannati.

6. Berdasarkan rasio hubungan antara variabel kenyamanan dan investasi, disimpulkan bahwa rumah yang memiliki rasio paling baik adalah Graha Satelit, selanjutnya Puri Citra Samawa, Bumi 
Samawa Damai dan terakhir Baiti Jannati.

7. Graha Satelit, Bumi Samawa Damai dan Baiti Jannati memiliki hubungan yang memperlihatkan bahwa semakin tingginya nilai kenyamanan bangunan, semakin tinggi pula biaya investasi yang dikeluarkan.

8. Berbeda dari tiga rumah lainnya, Puri Citra Samawa memiliki nilai kenyamanan urutan kedua setelah Graha Satelit, dengan nilai investasi paling rendah.

\section{DAFTAR RUJUKAN}

Ahmad,Wirawan. 2016. Investasi Bidang Property Di Sumbawa Makin Menggeliat. Diakses pada tanggal 20 Mei 2019.

Aflaki, A., Mahyuddin, N., Manteghi, G., Baharum, M. 2015. Building Height Effects on Indoor Air Temperature and Velocity in High Rise Residential Buildings in Tropical Climate. OIDA International Journal of Sustainable Development, ISSN 1923-6662.

Alfata, M., Hirata, N., Kubota, T., Nugroho, A., Uno, T., Antaryama, I., Ekasiwi, S. 2015. Thermal Comfort in Naturally Ventilated Apartments in Surabaya, Indonesia. Procedia Engineering, 121, 459-467.

Ashadi, Nelfiyanti dan Anisa. 2015. Pencahayaan dan Ruang Gerak Efektif sebagai Indikator Kenyamanan pada Rumah Sederhana Sehat Yang Ergonomis. Universitas Muhammadiyah Jakarta, Jakarta.

ASHRAE. (1989). ASHRAE Handbook Fundamentals. SI Edition. Atlanta: ASHRAE.Inc.

Badan Pusat Satistik Provinsi D.I. Yogyakarta. 2017. Statistik Perumahan Daerah Istimewa Yogyakarta 2017. Badan Pusat Statistik Provinsi Daerah Istimewa Yogyakarta. Yogyakarta

Badan Standarisasi Nasional. 2000. SNI 036197-2000 tentang Konservasi energi pada sistem pencahayaan. Jakarta: Badan Standarisasi Nasional.
Investasi Puri Citra Samawa paling kecil dikarenakan rendahnya nilai aksesibilitas tanah dan bangunan dibandingkan tiga rumah lainnya.

9. Berdasarkan hubungan kenyamanan dan investasi, diketahui bahwa investasi bangunan mempengaruhi kenyamanan ruang di dalamnya. Hal yang mempengarauhi tinggi rendahnya investasi rumah tidak hanya dari faktor desain bangunan, melainkan juga dari nilai aksesibilitas lahan dan bangunan.

Badan Standarisasi Nasional. 2001. SNI 036572-2001 tentang Tata cara perancangan sistem ventilasi dan pengkondisian udara pada bangunan gedung. Jakarta: Badan Standarisasi Nasional.

Djamila, H., Chu, C.M. dan Kumaresan, S. 2013. Field Study for Prediction and Evaluation of Comfort in Residential Buildings in the Equatorial HotHumid Climate of Malaysia. Building and Environment, 62, 133- 142.

Damiati, S., Zaki, S., Rijal, H.,Wonorahardjo, S. 2016. Field study on adaptive thermal comfort in office buildings in Malaysia, Indonesia, Singapore, and Japan during hot and humid season. Building and Environment, 109, 208223.

Fahira, Basong dan Tagala. 2010. Identifikasi Faktor Yang Mempengaruhi Nilai Jual Lahan dan Bangunan pada Perumahan Tipe Sederhana. Universitas Tadulako, Palu.

Fatma, Desy. 2018. 8 Faktor yang Mempengaruhi Kelembapan Udara dan Penjelasannya. Diakses 30 Januari 2019.

Frick, Heinz dan Mulyani, Tri Hesti. 2008. Arsitektur Ekologis: Konsep Arsitektur Ekologis di Iklim Tropis, Penghijauan Kota dan Kota Ekologis, serta Energi Terbarukan, Penerbit Kanisius, Yogyakarta.

Gedik, G., Akdağ, N., Kiraz, F., Şener, B., Çaçan, R. 2017. Evaluation of Mass 
Housing Settlements in Term of Wind and Noise Control: Istanbul and Diyabakir as a Case. Journal of Environmental Engineering and Landscape Management, 25, eISSN 1822-4199.

Grey, G.W. dan F.I. Deneke. 1978. Urban Forestry. John Wiley and Sons. Inc. New York

Jamaludin, N., Mohammed, N., Khamidi, M., Wahab, S. 2015. Thermal Comfort of Residential Building in Malaysia at Different Micro-climates. Social and Behavioral Sciences, 170, 613-623.

Kapoor, N., Tegar, J. 2018. Human Comfort Indicators Pertaining to indoor environmental quality paramaters of residential buildings in Bophal. International Research Journal of Engineering and Technology, 05, ISSN 2395-0056.

Kartika. 2003. Pengendalian Pengaruh Iklim Mikro terhadap Kenyamanan Thermal pada Rumah Sederhana di Daerah Pantai. Univessitas Islam Indonesia, Yogyakarta.

Keputusan Menteri Permukiman dan Prasarana Wilayah Nomor: 403/KPTS/M/2002 Tentang Pedoman Teknis Pembangunan Rumah Sederhana Sehat (RS Sehat). Jakarta. Menteri Permukiman Dan Prasarana Wilayah.

Keputusan Menteri Lingkungan Hidup. 1996. Keputusan Menteri Negara Lingkungan Hidup No. Kep48/MENLH/11/1996 tentang Baku Tingkat Kebisingan Sekretariat Negara. Jakarta.

Kementrian Kesehatan Republik Indonesia. 2011. Peraturan Menteri Kesehatan Republik Indonesia Nomor 1077/Menkes/Per/V/2011 tentang Pedoman Penyehatan Udara Dalam Ruang Rumah. Jakarta: Kementerian Kesehatan Republik Indonesia.

Latifah, Anugrah dan Garini. 2013. Kajian Sistem Pencahayaan yang Mempengaruhi Kenyamanan Visual pada Ruang A dan Ruang Sayap Galeri Selasar Sunaryo. Institut Teknologi Nasional, Bandung.
Latifah, Nur. 2013. Kajian Kenyamanan Termal pada Bangunan Student Center Itenas Bandung. Jurusan Teknik Arsitektur Fakultas Teknik Sipil dan Perencanaan. Institut Teknologi Nasional.

Lippsmeier, George. 1994. Bangunan Tropis. Erlangga. Jakarta.

Maltais, L., dan Gosselin, L. 2017. Daylighting 'energy and comfort' performance in office buildings: Sensitivity analysis, metamodel and pareto front. Journal of Building Engineering, 14, 61-72.

Meilani. 2013. "Teori Warna : Penerapan Lingkaran Warna dalam Berbusana". Jurusan Desain Komunikasi Visual, school of design. Jakarta : BINUS University

Nguyen, A., dan Reiter, Sigrid. 2011. The effect of ceiling configurations on indoor air motion and ventilation flow rates. Building \& Environment, 46, 1211-1222.

Ortiz, M., Kurvers, S., Bluyssen, P. 2017. A review of comfort, health, and energy use: Understanding daily energy use and wellbeing for the development of a new approach to study comfort. Energy and Buildings, 152, 323-335.

Prabowo, Dani. 2017. Setiap Tahun Ada 800.000 Unit Permintaan Rumah Baru. Kompas Edisi 21 Desember 2017. Diakses pada tanggal 28 November 2018.

Pratama, G. N. I. P., \& Sumarjo, H. (2018). Aksesibilitas Tata Letak Elevator Penumpang Gedung Kantor Pusat Layanan Terpadu (KPLT) Fakultas Teknik UNY. INformasi dan Ekspose hasil Riset Teknik Slpil dan Arsitektur, 14(1), 26-35.

Ramadhan, M. A., Pratama, G. N. I. P., \& Hidayah, R. (2018). Penataan Sistem Jalur Pejalan Kaki di Universitas Negeri Yogyakarta. INformasi dan Ekspose hasil Riset Teknik Slpil dan Arsitektur, 14(1), 101-117.

Santoso, Eddy. 2012. Kenyamanan Termal Indoor pada Bangunan di Daerah Beriklim Tropis Lembab. Indonesian Green Technology Journal. 
Satwiko. 2009. Pengertian Kenyamanan Dalam Suatu Bangunan. Yogyakarta: Wingjosoebroto

Setiawan, Moch. 2010. Tingkat Kebisingan pada Perumahan di Perkotaan. Universitas Negeri Semerang, Semarang.

Sugini. 2011. Hand out; Kenyamanan Termal. Yogyakarta. Jurusan Arsitektur Fakultas Teknik Sipil dan Perencanaan Universitas Islam Indonesia.

The National Optical Observatory. 2015. Recommended Light Levels. Diakses 15 April, 2019.

Wijaya, Ignatius. 2017. Teknik Optimasi Pencahayaan Alami dalam Interior Rumah Tinggal. Universitas Kristen Petra Surabaya, Surabaya.

Zuraida. 2015. Pengoptimalan Sirkulasi Angin Pada Rumah Deret. Seminar Nasional Teknologi, Institut Teknologi Nasional Malang.

Vaisi, S., Kharvari, F. 2019. Evaluation of Daylight regulations in buildings using daylight factor analysis method by radiance. Energy for Sustainable Development, 49, 100108.

Wolde, A., Pilon, C. 2007. The Effect of Indoor Humidity on Water Vapor Release in Homes. ASHRAE. 